The Tales of Belkin by A.S. Puškin 

DUTCH STUDIES IN RUSSIAN LITERATURE $\mid 1$

\section{The Tales of Belkin}

\section{by}

\section{A.S. Puškin}

Essays by

JAN VAN DER ENG Amsterdam

A. G. F. VAN HOLK Groningen

JAN M. MEIJER Utrecht

1968

MOUTON - THE HAGUE

PARIS 
(1) Copyright 1968 in The Netherlands.

Mouton \& Co. N.V., Publishers, The Hague.

No part of this book may be translated or reproduced in any form by print, photoprint, microfilm, or any other means, without written permission from the publishers.

Printed in The Netherlands by Mouton \& Co., Printers, The Hague. 